\title{
Evaluation of Mineral Contents in Milk of Dairy Cattle Fed Elephant Grass Planted at Ex-Coal Mining Land
}

\author{
H. Harmini ${ }^{a, *}$, D. Evvyernie ${ }^{b}$, P. D. M. H. Karti ${ }^{b}, \&$ Y. Widiawati \\ andonesian Research Institute for Animal Production (IRIAP), Bogor \\ Jalan Veteran III, Bogor 16720, Indonesia \\ ${ }^{b}$ Department of Nutrition and Feed Technology, Faculty of Animal Science, IPB University \\ (Bogor Agricultural University) \\ Jalan Agatis, Kampus IPB Dramaga Bogor 16680, Indonesia \\ *Corresponding author: hmini2011@gmail.com \\ (Received 03-10-2019; Revised 17-06-2020; Accepted 29-06-2020)
}

\begin{abstract}
The growth of several types of grass in the area of mine re-vegetation is rapidly providing an opportunity to be used as forages despite the possibility of heavy metal contamination. The purpose of the study was to evaluate the effect of treatment of different levels of elephant grass (EG) (Pennisetum purpureum) planted at ex-coal mining reclamation on milk productivity and mineral contents of dairy cattle. This study used four lactating (second lactation) dairy cattle using Latin Square Design of 4 (treatments) $x 4$ (replications). Each period was 21 days consisted of 14 days of preliminary for feed adaptation and 7 days for observation. Treatments were P0 (0\% ex-coal mining (EEG)+60\% Farmer's EG (FEG) $+40 \%$ Concentrate), P1 (15\% EEG $+45 \%$ FEG $+40 \%$ Concentrate), P2 (30\% EEG+30\% FEG $+40 \%$ Concentrate), and P3 (60\% EEG $+0 \%$ FEG $+40 \%$ Concentrate). The study observed variables of feed intake and efficiencies, milk production, milk quality, and mineral contents of milk. Results showed that EEG treatment at different levels did not affect fresh and dry matter intake. The highest fresh and dry matter intake was found in P0 treatment. There was no significant difference in giving EG planted at the ex-coal mining and the farmer's land on the milk production and milk quality. The only significant differences $(\mathrm{p}<0.05)$ were found in mineral Fe and $\mathrm{Mg}$ contents of milk. The study concluded that giving EG planted at the ex-coal mining area until $60 \%$ of forage affected Fe and Mg contents of milk, but they are still in the safe limit.
\end{abstract}

Keywords: ex-coal mining; elephant grass; heavy metal; milk production and quality

\section{INTRODUCTION}

Total coal productions in Indonesia are 419 million tons, while total coal productions in East Kalimantan are 236.6 million tons (Statistics Indonesia, 2018). National Standardization Agency of Indonesia (1998) stated that coal in East Kalimantan belongs to the moderate geological group, which is characterized by the slope of the layers and moderate variations in lateral density and the development of branching of coal seams. However, the distribution is still up to hundreds of meters. Coal reserves can be found beneath or above the surface of the earth, in which surface coal mining processes inevitably cause mine soils to degrade (Feng et al., 2019). Mining activities contain sulfide minerals such as coal, which triggers acid formation. The excavation process causes the uplifting of sulfide material to the surface. Consequently, oxidation occurs, resulting in a drastic decrease in soil humidity $(\mathrm{pH})$.

The mining industry area is often associated with the possibility of heavy metal contamination. The growth of several types of grass in the mine re-vegetation area quickly covers the land, and these grasses are useful for foraging and livestock grazing. The use of forage planted on ex-mining land, however, must be assessed as it may contain heavy metals. Hence, before its usage for food crops or forages, the ex-mining land reclamation must be carried out (Licina et al., 2017). The number of studies found that heavy metal is a general term that applies to groups of metals and metalloids of metals with a five or more density such as $\mathrm{Mn}, \mathrm{Cu}, \mathrm{Zn}$, $\mathrm{As}, \mathrm{Se}, \mathrm{Sb}$. These metals can cause human health problems, for example, cancer. It is because those metals can induce oxidative stress, as well as change the function of protein and DNA due to mining, smelting, industrial, agricultural, and sewage waste (Lim et al., 2019; Kim et al., 2019). Consumption of food containing heavy metals for human is a significant factor in exposure of heavy metals that causes detrimental health problems (Soekomo et al., 2011; Ali \& Malik, 2011; Donaldson et al., 2010).

Based on the results of a preliminary analysis at the laboratory, mineral contents of elephant grass (EG) planted in Integrated Dairy Farming (IDF) of KPC's ex coal-mining land was 110; 200; 0.45 and 64.19 ppm of $\mathrm{Mg} ; \mathrm{Fe} ; \mathrm{Pb}$ and $\mathrm{Mn}$, respectively. The feed given to the dairy cattle at IDF was EG planted at ex-coal mining land. Therefore, it becomes our concern in analyzing 
those minerals content in milk. The mineral contents in feed affect mineral contents in milk. This study evaluated the mineral contents of milk in dairy cattle fed with EG planted at the ex-coal mining land. The study will provide a valuable information on healthy milk for humans; especially, the milk comes from dairy cattle raised in the area of ex-coal mining land. There is a lack of studies to assess the potency of ex-coal mining land for livestock. This study will determine the possibility of this type of land used for forage-fed by livestock, notably, for dairy cattle, including the impact of this forage to milk quality in terms of heavy metals content.

\section{MATERIALS AND METHODS}

This research was conducted for 5 months (JulyNovember 2018) in integrated dairy farming (IDF) at PT Kaltim Prima Coal (KPC) Sangatta, East Kalimantan, Indonesia. This study used four $\mathrm{FH}$ dairy cattle $( \pm 5$ years of age; average body weight of $392.5 \pm 9.57 \mathrm{~kg}$ ) from Batu, Malang, Indonesia, at the second lactation period. Latin square was used for the experimental feeds treatments, namely $\mathrm{P0} \quad(0 \%$ ex-coal mining (0\%EEG $+60 \%$ FEG $+40 \%$ Concentrate), P1 (15\% EEG $+45 \%$ FEG $40 \%$ Concentrate), P2 (30\% EEG + 30\% FEG $+40 \%$ Concentrate), and P3 (60\% EEG + 0\% FEG $+40 \%$ Concentrate). Manure that enters the ditch automatically flows into the compost digester. The manure was then processed in the digester that will produce liquid fertilizer and biogas. The resulting liquid fertilizer was then distributed to the grass garden that was used for soil fertility and grass growth itself (Table 2). The grass was calculated based on nutrient contents of basal feeds,

Table 1. Nutrients content of basal feed used in the experiment

\begin{tabular}{lrrr}
\hline & & \multicolumn{2}{c}{ Elephant grass } \\
\cline { 3 - 4 } Nutrients & $\begin{array}{c}\text { Feed Pesat I } \\
\text { (Concentrate) }\end{array}$ & Farmer & $\begin{array}{r}\text { Ex-coal } \\
\text { mining }\end{array}$ \\
\hline Dry matter $(\%)^{1}$ & 100.00 & 100.00 & 100.00 \\
Ash $(\%)^{1}$ & 6.18 & 5.63 & 8.87 \\
Crude protein $(\%)^{1}$ & 11.56 & 8.76 & 11.32 \\
Extract ether $(\%)^{1}$ & 9.67 & 2.66 & 2.47 \\
Crude fiber $(\%)^{1}$ & 15.63 & 33.58 & 29.43 \\
NFE $(\%)^{1}$ & 44.92 & 17.36 & 16.43 \\
TDN $(\%)^{2}$ & 70.88 & 38.51 & 36.66 \\
Ca $(\%)^{1}$ & 0.97 & 0.25 & 0.27 \\
P (\%) ${ }^{1}$ & 0.62 & 0.14 & 0.47 \\
$\mathrm{Mg}(\mathrm{ppm})^{3}$ & 5056.092 & 2430.102 & 2766.892 \\
$\mathrm{Mn}(\mathrm{ppm})^{3}$ & 123.224 & 671.99 & 226.97 \\
$\mathrm{Fe}(\mathrm{ppm})^{3}$ & 160.03 & 54.99 & 168.621 \\
$\mathrm{~Pb}(\mathrm{ppm})^{3}$ & 0.005 & 3.636 & 6.251 \\
$\mathrm{As}(\mathrm{ppm})^{3}$ & 0.002 & 0.002 & 0.002 \\
$\mathrm{Hg}(\mathrm{ppm})^{3}$ & 0.132 & 0.012 & 0.416 \\
\hline $\mathrm{Not}$ & & &
\end{tabular}

Note: ${ }^{1}$ Laboratory Animal Feed Technology Pajajaran University; ${ }^{2}$ Formula TDN (Wardeh, 1981); TDN (\%DM) energy sources $=40.2625+0.19699 \mathrm{CP} \%)+0.4228(\mathrm{NFE} \%)+1.1903(\mathrm{EE} \%)-$ $0.1379(\mathrm{CF} \%)$. TDN (\%DM); forage $=1.6899+1.3844(\mathrm{CP} \%)-0.8279$ $(\mathrm{EE})+0.3673(\mathrm{CF} \%)+0.7526(\mathrm{NFE} \%)$

${ }^{3}$ Dairy Farming Nutrition Laboratory at IPB University. as shown in Table 1, in accordance with the nutrients required by lactating dairy cattle with a bodyweight of \pm $400 \mathrm{~kg}$, as mentioned in NRC (2001) for CP and TDN are $15 \%-16 \%$ and $67 \%-70 \%$, respectively.

\section{In Vivo Trial}

The experiment used 4 dairy cattle (average bodyweight of $392.5 \pm 9.57 \mathrm{~kg}$ ). The dairy cattle were treated with worm medicine and vitamin B before the experiment. The trial period was 3 months, divided by 4 periods each with of 21 days. Each period consisted of 14 days of preliminary period intended to eliminate the effect of the previous feed and adaptation to a new feed followed by a period for observation for 7 days. The experimental feed treatments are presented in Table 2. The amount of rations given per day to the experimental animals was based on dry matter (DM) required for their level of production being $3.5 \%$ of the live weight. The one day diet was divided into two parts and given twice a day (08.00 a.m. and 03.00 p.m.). Drinking water from the artificial river with $\mathrm{pH} 6.8$ was provided ad libitum.

The experimental cattle were milked twice a day, and the total milk production was recorded. The quality of milk was measured every day during the observation period using Lactoscan serial 14-9224 supply $12 \mathrm{~V}$ DC 50W made in Bulgaria. The sub-sample for mineral analysis was taken at the end of the study period. Fresh milk samples were taken from morning milking in a volume of $500 \mathrm{~mL}$ from each dairy cattle. Then the milk sample was put in a $100 \mathrm{~mL}$ polyethylene plastic sterile and stored at $4^{\circ} \mathrm{C}$. Sampling from the research location to the laboratory was carried out by storing samples
Table 2. Nutrients content of experimental feed treatments

\begin{tabular}{lcccc}
\hline \multirow{2}{*}{ Nutrients } & \multicolumn{4}{c}{ Treatments } \\
\cline { 2 - 5 } & P0 & P1 & P2 & P3 \\
\hline Dry matter (\%) & 48.5 & 48.4 & 48.2 & 47.8 \\
Ash (\%) & 5.85 & 6.34 & 6.82 & 7.79 \\
Crude protein (\%) & 9.88 & 10.26 & 10.65 & 11.42 \\
Extract ether (\%) & 5.46 & 5.44 & 5.41 & 5.35 \\
Crude fiber (\%) & 26.40 & 25.78 & 25.16 & 23.91 \\
TDN (\%) & 51 & 51 & 51 & 50 \\
Ca (\%) & 0.538 & 0.541 & 0.544 & 0.550 \\
P (\%) & 0.332 & 0.382 & 0.431 & 0.530 \\
Mg (ppm) & 3480.498 & 3531.02 & 3580 & 3680 \\
Mn (ppm) & 90 & 113.57 & 140 & 190 \\
Fe (ppm) & 97.006 & 114.05 & 131 & 165 \\
Pb (ppm) & 2.1836 & 2.58 & 2.981 & 3.7526 \\
As (ppm) & 0.002 & 0.002 & 0.002 & 0.002 \\
Hg (ppm) & 0.06 & 0.1206 & 0.1812 & 0.3024 \\
Feed composition (\%) & & & & \\
EEG & 0 & 15 & 30 & 60 \\
FEG & 60 & 45 & 30 & 0 \\
Concentrate & 40 & 40 & 40 & 40 \\
\hline
\end{tabular}

Note: $\mathrm{EEG}=$ ex-coal mining elephant grass; $\mathrm{FEG}=$ farmer elephant grass; $\mathrm{P} 0=0 \% \mathrm{EEG}+60 \% \mathrm{FEG}+40 \%$ Concentrate; $\mathrm{P} 1=15 \%$ EEG $+45 \%$ FEG + 40\% Concentrate; P2 $=30 \%$ EEG + 30\% FEG + 40\% Concentrate; $\mathrm{P} 3=60 \% \mathrm{EEG}+0 \% \mathrm{FEG}+40 \%$ Concentrate 
in a cool box containing dry ice and being taken to the dairy farming nutrition laboratory at IPB University to analyze the mineral contents.

\section{Variables Measurement}

The measurement of feed consumption was carried out by calculating the difference in the amount of feed given with the excess feed remaining every day during the study period. Consumption of feed (forage and concentrate) and DM intake were recorded. Measurements were carried out every 24 hours for 7 days in a period.

Milk production was calculated based on fat corrected milk (FCM) (NRC 2001). Technical efficiency (TE) was calculated by using the value based on milk production per unit of dry matter intake. In addition, the economic efficiency (EE) value was measured based on the profit from milk production on the feed cost used. The feed cost (1liter-1) of milk was estimated from the total feed cost used to produce every one liter of milk. Income over-feed cost of Milk (IOFC of Milk) (Price head $^{-1}$ day $^{-1}$ ) was calculated by reducing the income from milk sale by the cost of feed (Buza et al., 2014).

The study evaluated milk quality based on the composition of protein, fat, solid non-fat (SNF), dry milk ingredients, and lactose was tested by using Lactoscan (serial 14-9224 supply 12V DC 50W made in Bulgaria). Mineral contents in milk such as $\mathrm{Mg}$, $\mathrm{As}, \mathrm{Mn}, \mathrm{Fe}, \mathrm{Pb}, \mathrm{Hg}$ were also evaluated by using a spectrophotometer (IPB 2014).

\section{Data Analysis}

The data were analyzed by using analysis of variance (ANOVA) and any significant difference among treatments were tested by Duncan test (Steel \& Torrie, 1995) using software SPSS 16 , at the level $5 \%(p<0.05)$.

\section{RESULTS}

\section{Feed Consumption}

Feeding lactating cattle with EEG did not affect the consumption of fresh feed and nutrient (Table 3). Mineral consumption is calculated based on the usage of DM multiplied by the mineral content of the treatment ration. According to statistical analysis, offering the EEG with different levels did not alter the consumptions of $\mathrm{Pb}, \mathrm{Fe}, \mathrm{Mg}, \mathrm{Mn}, \mathrm{As}$, and $\mathrm{Hg}$.

\section{Milk Production, Technical Efficiency, Economic Efficiency, and IOFC}

Data on milk production, TE, EE, and IOFC of experimental dairy cattle are presented in Table 4 . The statistical analysis showed that feeding lactating cattle with EG from ex-coal mining land did not significantly affect the $4 \%$ FCM milk production. Based on the statistical analysis, there was no significant difference in the average values of the efficiency of technical ration in each treatment.

\section{Quality of Milk}

The results of the statistical analysis revealed that the feeding of the experimental cattle with EEG did not significantly affect the quality of milk, namely protein, fat, SNF, and lactose contents (Table 5). The average milk protein contents in treatments were similar for all the treatment groups.

\section{Mineral Contents in Milk}

Statistical analysis showed that experimental lactating cattle with EG from ex-coal mining land significantly

Table 3. The average consumption of fresh feed $\left(\mathrm{kg} \mathrm{head}^{-1}\right.$ day $\left.^{-1}\right)$ and nutrients in $\%$ dry matter $\left(\mathrm{g} \mathrm{head}^{-1}\right.$ day $\left.^{-1}\right)$ in dairy cattle

\begin{tabular}{|c|c|c|c|c|}
\hline \multirow{2}{*}{ Consumption } & \multicolumn{4}{|c|}{ Treatments } \\
\hline & P0 & P1 & P2 & P3 \\
\hline \multicolumn{5}{|c|}{ Fresh $\left(\mathrm{kg} \mathrm{head}^{-1}\right.$ day $\left.^{-1}\right)$} \\
\hline Elephant grass & $38.25 \pm 0.50$ & $38.25 \pm 0.95$ & $37.00 \pm 3.36$ & $37.00 \pm 2.82$ \\
\hline Concentrate & $9.25 \pm 0.95$ & $9.50 \pm 0.57$ & $9.50 \pm 0.57$ & $9.50 \pm 0.57$ \\
\hline \multicolumn{5}{|c|}{ Dry matter (g head ${ }^{-1}$ day $\left.^{-1}\right)$} \\
\hline Dry matter & $16937.47 \pm 545.60$ & $16125.14 \pm 1303.28$ & $16746.73 \pm 573.47$ & $16429.61 \pm 492.20$ \\
\hline Crude protein & $1717.64 \pm 60.78^{b}$ & $1700.49 \pm 139.16^{\mathrm{b}}$ & $1858.16 \pm 27.42^{\mathrm{a}}$ & $1880.165 \pm 55.85^{a}$ \\
\hline Crude fiber & $4898.16 \pm 615.05$ & $4045.58 \pm 188.15$ & $4076.57 \pm 37.08$ & $3666.09 \pm 144.09$ \\
\hline Extract ether & $1036.16 \pm 47.17$ & $957.26 \pm 118.82^{b}$ & $1037.96 \pm 21.56^{\mathrm{a}}$ & $1015.57 \pm 28.11$ \\
\hline TDN & $9068.09 \pm 359.09$ & $8547.69 \pm 888.54$ & $9142.57 \pm 224.02$ & $9228.39 \pm 320$ \\
\hline $\mathrm{Pb}(\mathrm{ppm})$ & $0.9532 \pm 0.01$ & $1.1347 \pm 0.02$ & $1.2621 \pm 0.09$ & $1.6086 \pm 0.11$ \\
\hline Fe (ppm) & $27.7791 \pm 0.87$ & $34.2293 \pm 2.19$ & $42.1845 \pm 2.03$ & $56.9388 \pm 2.75$ \\
\hline $\mathrm{Mg}(\mathrm{ppm})$ & $1059.193 \pm 29.58$ & $1048.2944 \pm 68.96$ & $1097.018 \pm 46.98$ & $1140.192 \pm 43.67$ \\
\hline Mn (ppm) & $186.3859 \pm 2.59$ & $157.3223 \pm 4.09$ & $125.9111 \pm 8.65$ & $68.8321 \pm 3.81$ \\
\hline As (ppm) & $0.0069 \pm 0.00$ & $0.006 \pm 0.00$ & $0.0068 \pm 0.00$ & $0.0068 \pm 0.00$ \\
\hline $\mathrm{Hg}(\mathrm{ppm})$ & $0.1200 \pm 0.00$ & $0.930 \pm 0.00$ & $0.0664 \pm 0.00$ & $0.0142 \pm 0.00$ \\
\hline
\end{tabular}

Note: TDN= Total digestible nutrient; $\mathrm{EEG}=$ ex-coal mining elephant grass; $\mathrm{FEG}=$ farmer elephant grass; $\mathrm{P} 0=0 \% \mathrm{EEG}+60 \% \mathrm{FEG}+40 \%$ Concentrate; $\mathrm{P} 1=$ $15 \%$ EEG $+45 \%$ FEG $+40 \%$ Concentrate; P2 $=30 \%$ EEG $+30 \%$ FEG $+40 \%$ Concentrate; P3 $=60 \%$ EEG $+0 \%$ FEG $+40 \%$ Concentrate. Means in the same row with different superscripts differ significantly $(\mathrm{p}<0.05)$. 
influenced the Fe and $\mathrm{Mg}$ contents of the milk produced (Table 6). The differences were found among the treatment groups. However, the statistical differences were not significant for $\mathrm{Pb}, \mathrm{Mn}, \mathrm{As}$, and $\mathrm{Hg}$ contents. The lowest average Fe content was found in P0 group, and the highest was found in $\mathrm{P} 3$ group. The average $\mathrm{Pb}$ contents in this study for treatment P0-P2 was 0.005 ppm, and P3 was $0.0063 \mathrm{ppm}$. The average As and $\mathrm{Hg}$ contents in this study for treatments were 0.003 and 0.005 ppm, respectively.

\section{DISCUSSION}

\section{Feed Consumption}

In the present study, the consumption of nutrients in dairy cattle was not affected by feeding with EEG. Dry matter intake (DMI) in the study was similar to the result reported by Olijhoek et al. (2018) that DMI at Freisien Holstein and Jersey cattle were $21100 \pm 3000 \mathrm{~g}$ day $^{-1}$ and $17400 \pm 2190 \mathrm{~g} \mathrm{day}^{-1}$, respectively. Trace mineral (TM) content of EEG was higher than FEG (Table 1). The result agreed with Miller et al. (2019) reporting that TM sources affected DMI. Additionally, DMI is influenced by the source roughage with its total mixed fiber (Maneerat et al., 2013) and forage particle size (Reynolds et al., 2018).

As a result, feeding the experimental dairy cattle with EEG did not affect the consumption of $\mathrm{CP}$. Crude protein intake is influenced by CP composition (Dickhoefer et al., 2018). Consumption of CP was influenced by the increasing level of protein in the feed. Therefore DMI, milk component, and yield, and feed efficiency will be increased with the increasing level of CP in the feed (Ramin et al., 2019; Zanton, 2016). The increased level of $\mathrm{CP}$ in the feed is related to the $\mathrm{N}$ content of the EG grown on the ex-coal mining land, since the application of manure compost on the land resulting in the increasing $\mathrm{N}$ content of grass- Nitrogen has a positive correlation with protein that low nitrogen and low phosphorus affect protein content and protein phosphorus, and low phosphorus had smaller influence than low $\mathrm{N}$ treatment (Toth et al., 2020; Andrianasolo et al., 2016).

Feeding dairy cattle with EEG did not affect the intake of crude fiber (CF). Dry matter, organic matter, NDF, ADF, and CP digestibilities affected dairy cattle

Table 4. Milk production, technical efficiency, economic efficiency, and income feed over cost (IOFC)

\begin{tabular}{lcccc}
\hline \multicolumn{1}{c}{ Variables } & \multicolumn{3}{c}{ Treatments } \\
\cline { 2 - 5 } \multicolumn{1}{c}{ P0 } & P1 & P2 & P3 \\
\hline Milk production FCM 4\% & $6.51 \pm 0.83$ & $6.79 \pm 0.96$ & $6.68 \pm 1.07$ & $0.67 \pm 0.90$ \\
Technical efficiency & $0.18 \pm 0.02$ & $0.19 \pm 0.02$ & $0.19 \pm 0.02$ & $0.22 \pm 0.03$ \\
Economic efficiency & $1.23 \pm 0.07$ & $1.30 \pm 0.30$ & $1.34 \pm 0.22$ & $1.58 \pm 0.23$ \\
Feed cost per liter of milk & $11477.34 \pm 1736.857$ & $10686.1 \pm 2036.29$ & $10318.47 \pm 1768.51$ & $8265.07 \pm 971.92$ \\
IOFC of milk (Rp e $\mathrm{er}^{-1}$ ) & $13423.08 \pm 4158.65$ & $21666.67 \pm 21320.9$ & $22946.43 \pm 15149.54$ & $35803.57 \pm 14601.63$ \\
\hline
\end{tabular}

Note: $\mathrm{EEG}=$ ex-coal mining elephant grass; FEG $=$ farmer elephant grass; $\mathrm{P} 0=0 \% \mathrm{EEG}+60 \% \mathrm{FEG}+40 \%$ Concentrate; P1 $=15 \%$ EEG $+45 \% \mathrm{FEG}+40 \%$ Concentrate; P2= 30\% EEG + 30\% FEG + 40\% Concentrate; P3= 60\% EEG + 0\% FEG + 40\% Concentrate.

Table 5. Data on the quality of milk taken from dairy cattle fed the experimental feed

\begin{tabular}{lcccc}
\hline \multirow{2}{*}{ Variables } & \multicolumn{3}{c}{ Treatments } \\
\cline { 2 - 5 } & P0 & P1 & P2 & P3 \\
\hline Protein (\%) & $2.69 \pm 0.17$ & $2.74 \pm 0.17$ & $2.76 \pm 0.06$ & $2.80 \pm 0.13$ \\
Fat (\%) & $4.95 \pm 0.81$ & $4.89 \pm 0.71$ & $4.93 \pm 0.48$ & $5.24 \pm 0.70$ \\
SNF (\%) & $7.65 \pm 0.38$ & $7.49 \pm 0.47$ & $7.53 \pm 0.18$ & $7.40 \pm 0.28$ \\
Lactose (\%) & $4.19 \pm 0.20$ & $4.11 \pm 0.26$ & $4.14 \pm 0.10$ & $4.06 \pm 0.15$ \\
\hline
\end{tabular}

Note: $\mathrm{EEG}=$ ex-coal mining elephant grass; $\mathrm{FEG}=$ farmer elephant grass; $\mathrm{P} 0=0 \% \mathrm{EEG}+60 \% \mathrm{FEG}+40 \%$ Concentrate; $\mathrm{P} 1=15 \%$ EEG $+45 \% \mathrm{FEG}+40 \%$ Concentrate; $\mathrm{P} 2=30 \% \mathrm{EEG}+30 \% \mathrm{FEG}+40 \%$ Concentrate; $\mathrm{P} 3=60 \% \mathrm{EEG}+0 \% \mathrm{FEG}+40 \%$ Concentrate.

Table 6. Data on mineral contents of milk produced from dairy cattle fed experimental feeds

\begin{tabular}{|c|c|c|c|c|c|}
\hline \multirow{2}{*}{ Mineral (ppm) } & \multicolumn{4}{|c|}{ Treatments } & \multirow{2}{*}{ Threshold } \\
\hline & P0 & P1 & P2 & P3 & \\
\hline $\mathrm{Pb}$ & $0.005 \pm 0$ & $0.005 \pm 0$ & $0.005 \pm 0$ & $0.0063 \pm 0.002$ & $\left.0.02^{*}\right)$ \\
\hline $\mathrm{Fe}$ & $0.160 \pm 0.001^{\mathrm{a}}$ & $0.0385 \pm 0.009 c$ & $0.0298 \pm 0.008^{b c}$ & $0.126 \pm 0.006^{b}$ & $\left.1.00^{* *}\right)$ \\
\hline $\mathrm{Mg}$ & $99.77 \pm 28.32^{\mathrm{a}}$ & $105.51 \pm 10.99^{a b}$ & $107.48 \pm 31.95^{b}$ & $109.51 \pm 14.37^{\mathrm{b}}$ & $\left.150^{* *}\right)$ \\
\hline $\mathrm{Mn}$ & $0.0105 \pm 0.001$ & $0.00807 \pm 0.0006$ & $0.0261 \pm 0.002$ & $0.0533 \pm 0.007$ & $\left.0.082^{* * *}\right)$ \\
\hline As & $0.002 \pm 0$ & $0.0035 \pm 0.001$ & $0.002 \pm 0$ & $0.0041 \pm 0.0001$ & $\left.0.1^{*}\right)$ \\
\hline $\mathrm{Hg}$ & $0.007 \pm 0.001$ & $0.005 \pm 0$ & $0.005 \pm 0$ & $0.006 \pm 0.002$ & $\left.0.03^{*}\right)$ \\
\hline
\end{tabular}

Note: "BSN (2011); ${ }^{* *}$ NRC (2001); ${ }^{* * *}$ FAO (2002); ${ }^{* * * *}$ Ogabiela et al. (2011); EEG= ex-coal mining elephant grass; FEG= farmer elephant grass; P0= 0\% EEG $+60 \%$ FEG + 40\% Concentrate; P1 $=15 \%$ EEG + 45\% FEG + 40\% Concentratee; P2=30\% EEG + 30\% FEG + 40\% Concentrate; P3= 60\% EEG + 0\% FEG $+40 \%$ Concentrate. Means in the same row with different superscripts differ significantly $(\mathrm{p}<0.05)$. 
nutrient digestibility (Fu et al., 2019). The result of CP intake found in the present study was similar to the data of Sousa et al. (2017) that showed 1650 up to 2007,5 $\mathrm{g} \mathrm{h}^{-1}$ day $^{-1}$. In addition, intake, such as total digestible nutrients, will decrease the nutritive value of diets for lactating dairy cattle (Cunha et al., 2013).

The current study found that fat intake was not affected by feeding lactating dairy cattle with EEG. This result agreed with Hess et al. (2019) who reported that the grain component of the basal diet did not affect milk yield of dietary fat supplements. Admittance levels and types of dietary energy sources, such as starch and fat, affected plasma metabolite profiles, milk production, and fertility of dairy cattle (Useni et al., 2018). In addition, feeding fats have a positive effect on fertility and a tendency to increase production when fed during the transition period (Rodney et al., 2015). However, fat consumption increased milk production and milk fat but decreased protein yield (Rabiee et al. (2012).

The study revealed that TDN had not been influenced by giving dairy cattle with EEG. This result agreed with the reults reported by Marchi et al. (2013) that pelleting and lignosulfonate treatments influenced diet intake and nutrient digestibility but were not affected by ground seeds. Additionally, TDN intake influenced CF, which is a source of roughage used in the diet was corn silage similar to diets based on a combination of two roughages (Alessio et al., 2018).

Consumption of TM was not affected by feeding the experimental dairy cattle with EEG. Diets should contain Mn at the levels of $30 \mathrm{ppm}$ at lactating and 50 ppm at dry cows (Safdar \& Kor, 2014). Additionally, a high $\mathrm{K}$ intake is the most important dietary factor that inhibits $\mathrm{Mg}$ absorption, which entails the risk of $\mathrm{Mg}$ deficiency, so supplementation of Magnesium oxide $(\mathrm{MgO})$ considerably applied in practice and recommended to increase $\mathrm{Mg}$ in the diet (Schonewille 2013).

\section{Milk Production, Technical Efficiency, Economic Efficiency, and IOFC}

Milk product of $4 \%$ FCM in this study was lower than that reported by Maneerat (2013), i.e., 12.36 \pm 2.56 to $15.10 \pm 2.09$, which resulted from the total mixed fiber. Maneerat (2013) highlighted that EG was better than pineapple silage but without significant effect on milk composition. Milk yield was not affected by fiber content (Gaafar et al. 2010), but it was affected by dietary protein and starch (Sucak et al., 2017). This study indicated that TE of milk production was low (Al-Sharafat, 2013). Economic efficiency (EE) in this study was similar to the results reported by Unakitan \& Kumbar (2019), i.e., 1.22. In addition, milk yield as a model input in intake predictions can be substantially affected by current dietary factors (Krizsan et al., 2014).

Furthermore, dietary forage and $\mathrm{CP}$ content will have positive economic and environmental impacts on dairy production under tropical conditions (Corea et al., 2017). EEG did not affect feed cost per liter of milk. Productivity, which plays a dominant role in a dairy farm, the cost of milk production could be reduced substantially if feeding practices and management of dairy animals are on scientific lines (Dubey et al., 2017. Optimal ration formulation rather than least-cost strategies may be vital in increasing milk yield and IOFC (Buza et al., 2014). Finally, the stochastic approach can be improved by using more inputs at the dairy farm level and considering the actual cost to measure profitability (Atzori et al., 2013).

\section{Quality of Milk}

The result of the protein content of milk recommended with BSN (2011) reported that the minimum protein content is $2.75 \%$. Nutrition affects the quality and component of milk (Tyasi et al., 2015). Moreover, milk production efficiency affected milk quality because of the efficiency of nutrient absorbtion was affected by dry matter intake (Martono et al., 2016) as well as improved forages qualities have the potential to increase milk production and milk quality (Mwendia et al., 2018). Particularly, iron contamination in bovine drinking or milk processing plant can change milk protein composition and oxidation in the final milk product, which decreases the quality and nutritional value of milk (Wang et al., 2016).

The result agreed with BSN (2011) that requires the minimum content of fat is $3.0 \%$. Additionally, improving milk fatty acid profiles and milk production can be the combined effects of corn stalk and other roughage (Liu et al., 2016). The high level of milk fat is affected by feed consumption, primarily forage consumption as a source of fiber. Diet is a source of nutrients for an animal that plays a role in the production and composition of milk. Milk fat levels can be affected by several factors, including the type of dairy cattle, age, lactation month, milking interval, environmental conditions, and diet consumption. Milk in tropical dairy herds consisted of fat, protein, lactose, and SNF 3.46; 3.39; 4.73, and 8.66 (Patricia et al., 2015).

In the present study, SNF meets the standard requirement of national standard (BSN, 2011), which requires the minimum content of $7.8 \%$. In the other study, SNF was affected by many factors such as the decrease of milk fat, the rise of milk dry matter and milk specific gravity (Adhani et al., 2012). Also, increasing dietary fiber content influenced the content of fat, protein, lactose, SNF, and total solid (TS) significantly (Gaafar et al., 2010).

In the present study, feeding the experimental dairy cattle with EEG did not affect the lactose content of milk. The result was similar to a previous study (Nichols et al., 2018) which reported that produced energy from fat and protein was the same when supplemented at isoenergetic levels. Furthermore, the formation of lactose was more affected by propionic acid, which comes from a concentrate or high-energy feed, and the higher concentrate content will decrease milk fat (Utami et al., 2014; Ramli et al., 2009). Therefore, lactose contributes to the energy value of milk and it is an essential ingredient for the food and pharmaceutical industries (Costa et al., 2019). 


\section{Mineral Contents of Milk}

The present study showed that dairy cattle fed with EEG affected $\mathrm{Fe}$ and $\mathrm{Mg}$ contents in milk. The result of this study was lower compared to a report by Manuelian et al. (2018) that parity, stage of lactation, and breed were essential contributors to milk mineral variation with $\mathrm{Mg}$. Also, the highest average of $\mathrm{Mg}$ content was ration with $60 \%$ elephant grass from ex-coal mining land. However, $\mathrm{Mg}$ content in milk was still below the average, according to NRC (2001), which was 150 ppm. Therefore, the higher the level of EEG, the higher the $\mathrm{Mg}$ content in milk. Retention and absorptions of $\mathrm{Mg}$ in dairy cattle relate to their requirements. $\mathrm{Mg}$ in feed rations must always be available. It is related to $\mathrm{Mg}$ retention and absorption in dairy cows. The age of dairy cattle had a significant effect on the average $\mathrm{Ca}$ and $\mathrm{Mg}$ contents of milk throughout lactation (Nogalska et al., 2017).

In the present study, feeding of experimental dairy cows with EEG significantly $(p<0.05)$ affected Fe contents in milk. The result was lower compared to previous reports (Davidov et al., 2019; NRC, 2001). The mineral contents of milk were affected by some factors such as soil, air, water, and environments. Moreover, $\mathrm{HM}$ has a strong relationship in soil, blood, and milk (Tahir et al., 2017). Also, Fe was an essential micromineral and needed in several biological processes, but if excessive, it will produce free radicals and attack sensitive tissues. The Fe originated from drinking water or iron supplements that cause oxidation, affect the composition and stability of milk protein, as well as the final milk quality (Wang et al., 2014; Ganz \& Nemeth, 2006). Several studies revealed that feed with Fe would increase competition for the absorption of $\mathrm{Mn}$ and $\mathrm{Cu}$ in the small intestine because these minerals were antagonistic to ruminants (Hansen \& Spears, 2009). The Fe was present in excessive amounts of feed, and it would be toxic because Fe would induce the production of Fe binding proteins in erythrocytes called ferritin (Goft et al., 2018).

The study revealed that mercury (Hg) was not found in the milk of dairy cattle fed with EEG. According to BSN (2011), the maximum toleration of $\mathrm{Hg}$ on milk is $0.03 \mathrm{ppm}$. Also, $\mathrm{Hg}$ was not found in any area with a high probability of being highly contaminated due to a mining zone (Montana et al. 2019. Therefore, metal concentration in dairy milk tends to increase with the increase in lactating age, which could be the cause of metals' ability to bio-accumulate (Kabir et al., 2017).

The study reported that arsenic (As) content of milk of dairy cattle was not affected by feeding with EEG. Also, it was reported that As content of milk in the area contaminated with mining land were $0.0184 \pm 0.0068$ and $0.1664 \pm 0.0423 \mathrm{ppm}$ in liquid and lyophilized milk, respectively (Montana et al., 2019). Besides, lactating livestock exposed to high levels of toxic metals $(\mathrm{Pb}, \mathrm{Sn}$, $\mathrm{Hg}, \mathrm{Cd}, \mathrm{Zn}, \mathrm{As}, \mathrm{Cu}$, and $\mathrm{Fe}$ ) accumulate these metals in their milk, thus posing a severe health risk for consumers (Ogut et al., 2016)

Mangan (Mn) is one of the essential minerals for dairy cattle. In the present study giving elephant grass from ex-coal mining land did not affect Mn content of milk. In the other study, the mineral profile in milk seems possible for many minerals, but it likely depends on genetics, environmental, and management factors in variable proportions according to the mineral considered (Stocco et al., 2019). The study reported that $\mathrm{Pb}$ content in fresh milk in a permittable concentration or a maximum of $0.02 \mathrm{ppm}$, according to BSN (2009). The contamination of milk came from multiple sources. There was a positive correlation between $\mathrm{Pb}$ and $\mathrm{As}$ concentrations in milk and water. Also, there was a positive correlation between $\mathrm{Cr}$ concentration and $\mathrm{Cd}$ concentration in milk and soil (Zhou et al., 2019). Gravert (1987) stated that HM in fresh milk of dairy cattle was absorbed from contaminated feed for around 5\%-10\% and then excreted through milk. Pb consumption in excessive amounts will be damage to the nervous system (BSN, 2009).

\section{CONCLUSION}

Treatment of elephant grass from ex-coal mining in Integrated Dairy Farming (IDF) increases the content of Fe and $\mathrm{Mg}$ minerals in milk. However, the ranges of Fe and $\mathrm{Mg}$ concentrations are still below the allowable threshold. Minerals of $\mathrm{Pb}, \mathrm{Fe}, \mathrm{Mg}, \mathrm{Mn}, \mathrm{As}$, and $\mathrm{Hg}$ in elephant grass of ex-coal mining were higher than the farmer's land elephant grass. However, those minerals grass of ex-coal mining were still safe to be consumed by dairy cattle to produce milk with allowable mineral contents of $\mathrm{Pb}, \mathrm{Fe}, \mathrm{Mg}$, $\mathrm{Mn}, \mathrm{As}$, and $\mathrm{Hg}$ in dairy milk.

\section{CONFLICT OF INTEREST}

We certify that there is no conflict of interest with any financial, personal, or other relationships with the other people or organizations related to the material discussed in the manuscript.

\section{ACKNOWLEDGEMENT}

This research was possible due to the research grant of The Ministry of Agriculture through the Indonesian Agency for Agricultural Research and Development (IAARD). Thanks to the staff at Integrated Dairy Farming (IDF) for their help during the experiment undertaken.

\section{REFERENCES}

Adhani N., T. Nurhajati, \& A. T. S. Estoepangestie. 2012. Potensi pemberian formula pakan konsentrat komersial terhadap konsumsi dan kadar bahan kering tanpa lemak susu. J. Agro Vet. 1: 11-16.

Alessio, D. R. M., J. P. Velho, V. C. P. Silveira, D. A. Knob, M. Busanello, A. A. C. Tambara, \& A. T. Neto. 2018. Roughage sources for Holstein cows under experimental feeding conditions in Brazil- a metaanalysis. Semina: Ciências Agrárias. 39: 2749-2760. https://doi. org/10.5433/1679-0359.2018v39n6p2749

Ali, S. M. \& R. N. Malik. 2011. Spatial distribution of metals in topsoils of Islamabad City, Pakistan. Environ. Monit. Assess. 172: 1-16. https://doi.org/10.1007/s10661-010-1314-x 
Al-Sharafat, A. 2013. Technical efficiency of dairy farms: A stochastic frontier application on dairy farms in Jordan. J. Agric Sci. 5: 45-52. https://doi.org/10.5539/jas.v5n3p45

Andrianasolo, F. N., L. Champolivier, P. Debaeke, \& P. Maury. 2016. Source and sink indicators for determining nitrogen, plant density, and genotype effects on oil and protein contents in sunflower achenes. Field Crops Res. 192: 33-41. https://doi.org/10.1016/j.fcr.2016.04.010

Atzori, A. S., L. O. Tedeschi, \& A. Cannas. 2013. A multivariate and stochastic approach to identify key variables to rank dairy farms on profitability. J. Dairy. Sci. 96: 3378-6256. https://doi.org/10.3168/jds.2012-6256

Statistics Indonesia. 2018. Indonesian Statistics. Statistics Indonesia. Jakarta. Indonesia

BSN (National Standardization Agency of Indonesia). 1998. Classification of coal resources and reserves. Standard Nasional Indonesia (National Standardization Agency of Indonesia) No. 13-5014-1998. Jakarta, Indonesia.

BSN (National Standardization Agency of Indonesia). 2009. Concentrated feed - part 1: dairy cows. Standard Nasional Indonesia (National Standardization Agency of Indonesia) No. 3148.1: 2009. Jakarta, Indonesia

BSN (National Standardization Agency of Indonesia). 2011. Fresh Milk-Part 1: Cow. Standard Nasional Indonesia (National Standardization Agency of Indonesia) No. 3141: 2011. Jakarta, Indonesia.

Buza, M. H., L. A. Holden, R. A. White, \& V. A. Ishler. 2014. Evaluating the effect of ration composition on income feed cost and milk yield. J. Dairy Sci. 97: 3073-3080. https://doi. org/10.3168/jds.2013-7622

Corea, E. E., J. M. Aguilar, N.P. Alas, E. A. Alas, J. M. Flores, \& G. A. Broderick. 2017. Effects of dietary cowpea (Vigna sinensis) hay and protein level on milk yield, milk composition, $\mathrm{N}$ efficiency, and profitability of dairy cows. Anim. Feed. Sci. Tech. 226: 48-45. https://doi.org/10.1016/j. anifeedsci.2017.02.002

Costa, A, N. Lopez-Villalobos, N. W. Sneddon, L. Shallo, M. Franzoi, M. De Marchi, \& M. Penasa. 2019. Invited review: Milk lactose - current status and future challenges in dairy cattle. J. Dairy Sci. 102: 5883-5898. Animal. 1:1-8. https://doi.org/10.3168/jds.2018-15955

Cunha, O. F. R., J. N. M. Neiva, R. P. Maciel, J. Restle, V. L. Araujo, J. Paiva, \& F. R. C. Miotto. 2013. Palm (Elaeis guineensis L.) kernel cake in diets for dairy cows. Semina: Ciências Agrárias, Londrina. 34:445-454. https://doi. org/10.5433/1679-0359.2013v34n1p445

Davidov I, Z. Kovacevic, D. Stojanovic, M. Pucarevic, M. Radinovic, N. Stojic \& M. Erdeljan. 2019. Contamination of cow milk by heavy metals in Serbia. Acta Sci. Vet. 47:1-4. https://doi.org/10.22456/1679-9216.96366

Dickhoefer, U., S. Glowacki, C.A. Gomez \& J.M. CastroMontoya. 2018. Forage and protein use efficiency in dairy cows grazing a mixed grass-legume pasture and supplemented with different levels of protein and starch. Livest. Sci. 216: 109-118. https://doi.org/10.1016/j.livsci.2018.08.004

Donaldson, S.G, J. Van Potsdam, C. Tikhonov, M. Feeley, B. Armstrong, P. Ayotte, O. Boucher, W. Bowers, L. Chan, F. Dallaire, R. Dallaire, É. Dewailly, J. Edwards, G. M. Egeland, J. Fontaine, C. Furgal, T. Leech, E. Loring, G. Muckle, T. Nancarrow, D. Pere, P. Plusquellec, M. Potyrala, O. Receveur, \& R. G. Shearer. 2010. Environmental contaminants and human health in the Canadian Arctic. Sci Total Environ. 408: 5165-5234. https:// doi.org/10.1016/j.scitotenv.2010.04.059

Dubey, M., V. P. Singh, R. K. Pandey, \& A. K. Chaubey. 2017. Economic analysis of feeding management and milk production at the University Dairy Farm. Int. J. Curr. Microbiol. App. Sci. 6: 480-486. https://doi.org/10.20546/ ijcmas.2017.602.054
FAO (Food Agricultural Organization). 2002. Codex Alimentarius-general standards for contaminants and toxins in food. Schedule 1 Maximum and guideline levels for contaminants and toxins in food, Joint $\mathrm{FAO} / \mathrm{WHO}$ food standards programme: Codex committee. Reference CX/ FAC 02/16. Rotterdam.

Feng, Y., J. Wang, Z. Bai, \& L. Reading. 2019. Effects of surface coal mining and land reclamation on soil properties: A review. Earth-Science Reviews 191: 12-25. https://doi. org/10.1016/j.earscirev.2019.02.015

Fu, Q., W. Shen, Z. Wei, P. Zheng, H. Xin, \& C. Zhao. 2019 Prediction of the diet nutrients digestibility of dairy cows using Gaussian process regression. Information Processing in Agricultural 6: 396-406. https://doi.org/10.1016/j. inpa.2018.11.005

Gaafar, H. M. A., E. M. Abdel-Raouf, \& K. F. A. El-Reidy. 2010. Effect of fibrolytic enzyme supplementation and fiber content of total mixed ration on productive performance of lactation buffaloes. Slovak. J. Anim. Sci. 43: 147-153. https://sjas.ojs.sk/sjas/article/view/347/335

Ganz, T. \& E. Nemeth. 2006. Regulation of iron acquisition and iron distribution in mammals. BBA-Molecular Cell Research. 1763: 690-699. https://doi.org/10.1016/j. bbamcr.2006.03.014

Goft, J. P. 2018. Invited review: Mineral absorption mechanism, mineral interactions that affect acid-base and antioxidant status, and diet considerations to improve mineral status, and diet consideration to improve mineral status. J. Dairy Sci. 101:2763-2813. https://doi.org/10.3168/jds.2017-13112

Gravert, H. O. 1987. Dairy Cattle Production. World Animal Science. Elsevier Science Publishers B.V., Amsterdam.

Hansen, S. L \& W. Spears. 2009. Bioaccessibility of iron soil is increased by silage fermentation. J. Dairy Sci. 92: 28962905. https://doi.org/10.3168/jds.2008-1933.

Hess, P. S., S. R. O. William, J. L. Jacobs, M. C. Hannah, K. A. Beauchemin, R. J. Eckard, W. J. Wales, G. L. Morris, \& P. J. Moate. 2019. Effect of dietary fat supplementation on methane emissions from dairy cows fed wheat or corn. J. Dairy Sci. 102: 2714-2723. https://doi.org/10.3168/ jds.2018-14721

IPB (Institut Pertanian Bogor). 2014. Standard Operational Procedures for Mineral Analysis Preparation. Bogor.

Kabir, A., K. Khan, M. I. H.Khan, T. Jubair, \& E. Jhahan. 2017. A study of heavy metal presence in cow milk of different dairy farms near Karnafuli paper mills, Chittagong, Bangladesh. AJER. 6: 329-333.

Kim, J. J, Y. S. Kim, \& V. Kumar. 2019. Heavy metal toxicity: An update of chelating therapeutic strategies. J. Trace Elements Med. Biol. 54: 226-231. https://doi.org/10.1016/j. jtemb.2019.05.003

Krizsan, S. J., A. Sairanen, A. Hojer, \& P. Huhtanen. 2014. Evaluation of different feed intake models for dairy cows. J. Dairy Sci. 97: 2387-2397. https://doi.org/10.3168/ jds.2013-7561

Licina V, M. F. Aksic, Z. Tomic, I. Trajkovic, S. A. Mladenovic, M. Marjanovic, \& J. Rinklebe. 2017. Bioassessment of heavy metals in the surface soil layer of an opencast mine aimed for its rehabilitation. Journal of Environmental Management 186: 240-252. https://doi.org/10.1016/j. jenvman.2016.06.050

Lim, J. T., Y. Q. Tan, L. Valeri, J. Lee, P. P Geok, S. E. Chia, C. N. Ong, \& W. J Seow. 2019. Association between serum heavy metals and prostate cancer risk - A multiple metal analysis. Environmental International 132: 1-10 https://doi. org/10.1016/j.envint.2019.105109

Liu, S., R. Zhang, R. Kang, J. Meng, \& C. Ao. 2016. Milk fatty acids profiles and milk production from dairy cows fed different forage quality diets. Anim. Nut. https://doi. org/10.1016/j.aninu.2016.08.008 
Marchi, F. E., F. J. F. Figueiroa., G. T. Santos., W. B. R. Santos. D. C. S. Kazama, A. F. Branco. L. C. Leite, \& J. C. Damasceno. 2013. Intake, digestibility, and ruminal parameters of dairy cows fed pelleted diets and treated with lignosulfonatecontaining sunflower seeds. R. Bras. Zootec. 42: 656-663. https://doi.org/10.1590/S1516-35982013000900008

Maneerat, W., S. Prasanpanich, P. Kongmun, W. Sinsmut, \& S. Tumwasorn. 2013. Effect of feeding total mixed fiber on feed intake and milk production in mid-lactating dairy cows. Kasetsart J. (Nat. Sci.). 47: 571-580.

Manuelian, C. L., M. Penasa, G. Visentin, A. Zidi, M. Cassandro, \& M. D. Marchi. 2018. Mineral composition of cow milk from multibreed herds. Anim. Sci. J. 89: 16221627. https://doi.org/10.1111/asj.13095

Martono, S., W. Negara, R.A. Gopar, \& M. N. Rofiq. 2016. Combination effect of feed supplements on milk yield and milk quality of dairy cattle. J. Adv. Agri. Tech. 3: 136-139. https://doi.org/10.18178/joaat.3.2.136-139

Miller, M. D., J. S. Lanier, S. K. Kvidera, H. M. Dann, C. S. Ballard, \& R. J. Grant. 2019. Evaluation of source of corn silage and trace minerals on lactational performance and total-tract nutrient digestibility in Holstein cows. J. Dairy Sci. 103: 1-14. https://doi.org/10.3168/jds.2019-17716

Montana, J. R. G., E. Senis, A. J. Alonso, M. E. Alonso, M. P. Alonso, \& J. C. Dominguez. 2019. Some toxic metals (Al, As, Mo, Hg) from cow's milk raised in a possibly contaminated area by different sources. Environ. Sci. Pollut. Res. 26: 28909-28918. https://doi.org/10.1007/s11356-019-06036-7

Mwendia, S. N., C. M. Mwungu, S. K. Ng'ang' a, D. Njenga, \& A. Notenbaert. 2018. Effect of feeding oat and vetch forages on milk production and quality in smallholder dairy farms in Central Kenya. Trop. Anim. Health Prod. 50: 1051-1057. https://doi.org/10.1007/s11250-018-1529-3

NRC (National Research Council). 2001. Nutrient Requirement of Dairy Cattle. $7^{\text {th }}$ Ed. Revised edition: Natl. Acad. Sci, Washington.

Nichols, K., A. Bannink, S. Pacheco, H. J. Van Valenberg, J. Dijkstra, \& H. Van Laar. 2018. Feed and nitrogen efficiency are affected differently, but milk lactose production is stimulated equally when isoenergetic protein and fat is supplemented in lactating dairy cow diets. J. Dairy Sci. 1010: 7857-7870. https://doi.org/10.3168/jds.2017-14276

Nogalska, A., M. Momot, M.Sobczuk-Szul, P. PogorzelskaPrzybylek, \& Z. Nogalski. 2017. Calcium and magnesium content in the milk of high yielding cows. J. Elem. 22: 809815. https://doi.org/10.5601/jelem.2016.21.4.1365

Ogabiela, E. E., U. U. Udiba, O. B. Adesina, C. Hammuel, F. A. Ade-Ajayi, G. G. Yebpella, U. J. Mmereole, \& M. Abdullahi. 2011. Assessment of metal levels in fresh milk from cattle grazed around Challawa Industrial Estate of Kano, Nigeria. J. Basic. Appl. Sci. Res. 1: 533-538.

Ogut, S., H. S. Canbay, \& H. Uludag. 2016. Effect of environmental factors on heavy metal content of raw milk. Akademik Gida. 14: 105-110.

Olijhoek, D. W., P. Lovendahl, J. Lassen, A. L. F. Hellwing, J. K. Hoglund, M. R. Weisbjerg, S. J. Noel, F. McLean, O. Hojberg, \& P.Lund. 2018. Methane production, rumen fermentation, and diet digestibility of Holstein and Jersey dairy cows being divergent in residual feed intake and fed at 2 forage-to-concentrate ratios. J. Dairy Sci. 101: 99269940. https://doi.org/10.3168/jds.2017-14278

Patricia, C. A., H. B. Antonio, D. M. Belisario, \& M. P. Felipe. 2015. Variation in milk yield and composition in cows in tropic of Veracruz State, Mexico. Res. Opim. Anim. Vet. Sci. 1: 34-37.

Rabiee, A. R., K. Breinhild, W. Scott, H. M.Golder, E. Block, \& I.J. Lean. 2012. Effect of fat additions to diets of dairy cattle on milk production and components: A meta-analysis and meta-regression. J. Dairy Sci: 95: 3225-3247. https://doi. org/10.3168/jds.2011-4895

Ramin, M., M. Franco, M. Y. Roleda, I. M. Aasen, M. Hetta, \& H. Steinshamn. 2019. In vitro evaluation of utilizable crude protein and methane production for diet in which grass silage was replaced by different levels and fractions of extracted seaweed proteins. Anim. Feed Sci. Technol. 255: 1-12. https://doi.org/10.1016/j.anifeedsci.2019.114225

Ramli, N., M. Ridla, T. Toharmat, \& L. Abdullah. 2009. Milk yield and milk quality of dairy cattle fed silage complete ration based on selected vegetable waste as fibre sources. J. Indon. Trop. Anim. Agric. 34: 36-41.

Reynolds, M. A., T.M. Brown-Brandl, J. V. Judy, K. J. Herrick, K. E. Watson, \& P.J. Kononoff. 2018. Use of indirect calorimetry to evaluate utilization of energy in lactating Jersey dairy cattle consuming common coproducts. J. Dairy Sci. 102: 320-333. https://doi.org/10.3168/jds.2018-154471

Rodney, R. M., P. Celi, W. Scott, K. Breinhild \& I. J. Lean. 2015. Effects of dietary fat on fertility of dairy cattle: A metaanalysis and meta-regression. J. Dairy Sci. 98: 5601-9528. https://doi.org/10.3168/jds.2015-9528

Safdar, A. H. S. \& N. M. Kor. 2014. Trace mineral requirements for dairy cattle. Int. J. Adv. Biom. Res. 2: 427-432.

Schonewille, J. 2013. Magnesium in dairy cow nutrition: an overview. Plant Soil 368: 167-178. https://doi.org/10.1007/ s11104-013-1665-5

Soekomo, C. B., E. Nkurang, D. P. Rousseau, \& P. N Lens. 2011. Fate of heavy metals in an urban natural wetland: the Nyabugogo Swamp (Rwanda). Water Air Soil Pollut. 214: 321-333. https://doi.org/10.1007/s11270-010-0426-9

Sousa, D. O., B. D. S. Mesquita, A. V. Pires, M. H. D. A. Santana, \& L. F. P. Silva. 2017. Effect of fibre digestibility and level of roughage on performance and rumen fermentation of finishing beef cattle. Trop. Anim. Health. Prod. 49: 1503-1510. https://doi.org/10.1007/s11250-017-1353-1

Sucak, M. G, U. Serbester, \& M. Gorgulu. 2017. Effect of dietary starch and crude protein levels on milk production and composition of dairy cows fed high concentrate diet. Turkish J. Agri-Food Sci. Tech. 5: 563-567. https://doi. org/10.24925/turjaf.v5i6.563-567.718

Steel, R. G. D. \& J. H Torrie. 1995. Principles and Procedures of Statistics. $2^{\text {nd }}$ Ed. Translated by Bambang S. PT. Gramedia Pustaka Utama, Jakarta.

Stocco, G., A. Summer, M. Malacarne, A. Cecchinato, \& G. Bittante. 2019. Detailed macro-and micromineral profile of milk: effects of herd productivity, parity, and stage of lactation of cows of 6 dairy and dual-purpose breeds. J. Dairy Sci. 102: 9727-9739. https://doi.org/10.3168/jds.2019-16834

Tahir, M., M. Iqbal, M. Abbas, M. A. Abbas, M. A. Tahir, A. Nazir, D. N. Iqbal, Q. Kanwal, F. Hassan, \& U. Younas. 2017. Comparative study of heavy metals distribution in soil, forage, blood, and milk. Acta Ecologica Silica. 37: 207212. https://doi.org/10.1016/j.chnaes.2016.10.007

Toth, B., A. V. Biljon \& M. Labuschagne. 2020. Influence of low soil nitrogen and phosphorus on gluten polymeric and monomeric protein distribution in two high-quality spring wheat cultivars. Journal of Cereal Science 91: 1-6. https:// doi.org/10.1016/j.jcs.2019.102867

Tyasi, T. L., C. P. Tlabela, \& M. Gzasheka. 2015. Assessing the effect of nutrition on milk composition of dairy cows: A review. Int J. Curr. Sci. 17: 56-63.

Wang, H., Y. Liu, Z. Qi, S. Wang, S. Liu, X. Li, H. Wang, X. Wang, X. Xia, \& X. Zhu. 2014. The estimation of soil trace elements distribution and soil-plant-animal continuum in relation to trace elements status of sheep in Huangcheng area of Qilian mountain grassland, China. J Integrative Agriculture 13: 140-147. https://doi.org/10.1016/ S2095-3119(13)60504-3

Wang, A., S. E. Duncan, K. F. Knowlton, W. K. Ray, \& A. M. Dietrich. 2016. Milk protein composition and stability 
changes affected by iron in water sources. J. Dairy Sci. 99: 1-14. https://doi.org/10.3168/jds.2015-10481

Wardeh, M. F. 1981. Models For Estimating Energy and Protein Utilization For Feeds. Utah State Univ Pr, Utah.

Unakitan, G., N. Kumbar. 2019. Analysis of feed conversion efficiency in dairy cattle farms in Thrace Region, Turkey. Energy 176: 589-595. https://doi.org/10.1016/j. energy.2019.04.031

Useni, B. A., C. J. C. Muller, \& C. W. Cruywagen. 2018. Pre and postpartum effects of starch and fat in dairy cows: A review. S. Afr. J. Anim. Sci. 48: 413-426. https://doi. org/10.4314/sajas.v48i3.2
Utami, K. B., L. E. Radiati, \& P. Surjowardojo. 2014. Kinerja peternak sapi perah PFH (Studi kasus pada anggota Koperasi Agro Niaga) di Kecamatan Jabung Kabupaten Malang. Jurnal Ilmu-Ilmu Peternakan. 24: 56-66.

Zanton, G. I. 2016. Analysis of production responses to changing crude protein levels in lactating dairy cow diets when evaluated in continuous or change-over experimental designs. J. Dairy Sci. 99: 4398-4410. https://doi.org/10.3168/ jds.2015-10438

Zhou, X., N. Zheng, C. Su, J. Wang, \& H. Soyeurt. 2019. Relationships between $\mathrm{Pb}$, As, $\mathrm{Cr}$, and $\mathrm{Cd}$ in individual cattle milk and milk composition and heavy metal contents in water, silage, and soil. Environmental Pollution 255: 1-26. https://doi.org/10.1016/j.envpol.2019.113322 